\title{
Biocontrol Efficacies of Bacillus Species Against Cylindrocarpon destructans Causing Ginseng Root Rot
}

\author{
Yelim Jang, Sang Gyu Kim and Young Ho Kim* \\ Department of Agricultural Biotechnology and Center for Agricultural Biomaterials, Seoul National University, Seoul 151-921, \\ Korea \\ (Received on July 19, 2011; Revised on October 4, 2011; Accepted on October 4, 2011)
}

Two antifungal bacteria were selected from forest soils during the screening of microorganisms antagonistic to Cylindrocarpon destructans, a cause of ginseng root rot. The antifungal bacteria were identified as Bacillus subtilis (I4) and B. amyloliquefaciens (yD16) based on physiological and cultural characteristics, the Biolog program, and 16S rRNA gene sequencing analyses. Antagonistic activity of both bacterial isolates to $C$. destructans increased with increasing temperature. More rapid starch hydrolytic activity of the bacteria was seen on starch agar at higher temperatures than at lower temperatures, and in the higher density inoculum treatment than in the lower density inoculum treatment. The bacterial isolates failed to colonize ginseng root the root tissues inoculated with the bacteria alone at an inoculum density of $1 \times 10^{6} \mathrm{cfu} / \mathrm{ml}$, but succeeded in colonizing the root tissues co-inoculated with the bacteria and $C$. destructans. Scanning electron microscopy showed that the pathogen was damaged by the low-density inoculum treatment with the bacterial isolates as much as by the high-density inoculum treatment. Both bacterial isolates were more effective in reducing root rot when they were treated at a concentration of $1 \times 10^{6} \mathrm{cfu} /$ $\mathrm{ml}$ than at $1 \times 10^{8} \mathrm{cfu} / \mathrm{ml}$. Also, only the former treatment induced prominent wound periderm formation, related to structural defense against pathogen infection. The results suggest that the bacterial antagonists may have high potential as biocontrol agents against ginseng root rot at relatively low-inoculum concentrations.

Keywords : Bacillus species, biological control, Cylindrocarpon destructans, ginseng root rot

Ginseng (Korean ginseng) (Panax ginseng Meyer, Araliaceae) is recognized in the Orient a very important medicinal plant. During ginseng cultivation, plants may be attacked by a variety of biotic agents, especially soil-borne pathogens, such as fungi, bacteria, and nematodes, among which

\footnotetext{
*Corresponding author.

Phone) +82-2-880-4675, FAX) +82-2-873-2317

E-mail)yhokim@snu.ac.kr
}

Cylindrocarpon destructans is most responsible for ginseng root rot and is one of the main causes of long-term replant problems (Chung, 1975; Jeon et al., 2008; Kim et al., 2006; Lee, 2004; Ohh et al., 1983; Park, 2001; Yu, 1987; Yu and Ohh, 1993). One of conventional control methods for fungal diseases is the use of chemical fungicides (Agrios, 2005). However, chemical control of soil-borne diseases is expensive and rarely achieves full disease control; other disadvantages include potential environmental hazards, toxicity to crops, and development of fungicide-resistant strains (Hass and Defago, 2005; Handelsman and Stabb, 1996). Biocontrol of plant pathogens is an alternative means of reducing the incidence and severity of diseases with no or few negative impacts on the environment compared to chemical controls with fungicides.

Over a hundred microbial products are currently registered or marketed as biocontrol agents worldwide (Whipps and McQuiken, 2009), and presently 14 microbial fungicides are commercially registered in Korea (Kim et al., 2010). Four bacterial strains were reported to be effective for control of ginseng diseases such as Phytophthora blight caused by Phytophthora cactorum and root rot caused by $C$. destructans (Bae et al., 2004; Sang et al., 2006). Two bacterial isolates strongly antagonistic to $C$. destructans were isolated during the survey of biocontrol agents for ginseng root rot. They were identified and exaimned their biocontrol activity for use in practical applications to control ginseng root rot.

\section{Materials and Methods}

Pathogen preparation for disease development. Cylindrocarpon destructans KACC 41077 was obtained from The Korean Agricultural Culture Collection (KACC), Rural Development Administration (RDA), Suwon, Korea, and used in this experiment after confirming its pathogenicity to ginseng roots, of which the inoculation methods and resulting disease severity were almost identical to those for the inoculation control in pot experiments in this study. The fungus was cultured on potato-dextrose agar (PDA) at 
$21^{\circ} \mathrm{C}$ for 14 days. This fungal culture was used directly as a pathogen inoculum or cultured again on rice hull medium (rice hull 1: sand 4: distilled water 1.5) for use as a pathogen inoculum for pot experiments.

In vitro screening of bacteria with antifungal activity against $C$. destructans. For biological control of $C$. destructans, 174 bacterial isolates were collected from forest soils in various mountain areas, mushrooms, and crop fields in Korea and screened for antifungal activity against $C$. destructans. Mycelial discs (1-cm in diameter) of the fungus grown for 14 days on PDA as described above were placed in the center of PDA plates. The bacterial isolates were grown in brain heart infusion (BHI) (CONDA, Madrid, Spain) broth at $28^{\circ} \mathrm{C}$ for 2 days with shaking at $200 \mathrm{rpm}$, and $10 \mu \mathrm{l}$ of the bacterial suspensions were spotted on PDA plates $3 \mathrm{~cm}$ apart from the mycelial discs. Sterile distilled water (SDW) was used as the untreated control. After incubation for 14 days, the inhibitory activity was measured for each bacterial isolate as the mycelial growth of $C$. destructans. Three replications were used for each treatment.

Identification of antifungal bacteria. Among the bacteria, two isolates with the highest antifungal activity against $C$. destructans were selected for further biocontrol study. These isolates were identified based on physiological and culture characteristics, and analysis with the Biolog program. To confirm bacterial identities, 16s rRNA gene sequences of the isolates were analyzed using the $27 \mathrm{mF}$ (5'-AGAGTTTGATCM-TGGCTCAG-3') and $1492 \mathrm{mR}$ (5'-GGYTACCTTGTTACG-ACTT-3') primers (Brosius et al., 1978; Weisburg et al., 1991) after PCR amplification of the 16s rRNA gene. The resulting sequences were analyzed using Blast search program in GenBank and compared with other sequences listed in GenBank.

Antifungal activities of bacteria with different nutrients and temperatures. $C$. destructans KACC 41077 was grown on PDA at $21^{\circ} \mathrm{C}$ for 2 weeks and mycelial discs of $1-\mathrm{cm}$ diameter were placed in the center of modified PDA plates with various PD broth concentrations $(0,25,50,75$, and $100 \%)$. The bacterial suspensions $(10 \mu \mathrm{l})$ from the bacterial cultures grown in $\mathrm{BHI}$ broth at $28^{\circ} \mathrm{C}$ for 2 days with shaking at $200 \mathrm{rpm}$ were spotted on PDA plates $3 \mathrm{~cm}$ apart from the mycelial discs. Then, the plates were incubated at $21^{\circ} \mathrm{C}$. SDW was used as the control. After incubation for 14 days, inhibitory activity was measured for each bacterial isolate as $\%$ inhibition of mycelial growth of C. destructans relative to the mycelia growth in the control. Three replications were used for each treatment.

Mycelial discs (1-cm in diameter) of $C$. destructans
KACC 41077 grown on PDA at $21^{\circ} \mathrm{C}$ for 2 weeks were placed in the center of Czapek-Dox agar plates and spotted at $3 \mathrm{~cm}$ intervals with $10 \mu \mathrm{l}$ bacterial suspension, grown in BHI broth at $28^{\circ} \mathrm{C}$ for 2 days with shaking at $200 \mathrm{rpm}$. These plates were incubated at $15,18,21,25$, and $28^{\circ} \mathrm{C}$. SDW was used as the control. After incubation for 14 days, the inhibitory activity was measured for each bacterial isolate as mycelial growth of $C$. destructans. Three replications were used for each treatment.

Starch hydrolytic activity of antifungal bacteria. Starch hydrolytic activity of the bacterial isolates was tested as enzyme activity related to ginseng root rotting in previous studies (Jeon et al., 2003, 2010). For this, aliquots (10 $\mu$ l) of each bacterial suspension at inoculum densities of $1 \times 10^{4}$ $\mathrm{cfu} / \mathrm{ml}, 1 \times 10^{6} \mathrm{cfu} / \mathrm{ml}$, and $1 \times 10^{8} \mathrm{cfu} / \mathrm{ml}$ were spotted on modified starch agar plates ( $3 \mathrm{~g}$ beef extract, $5 \mathrm{~g}$ peptone, 2 $\mathrm{g}$ soluble starch, and $15 \mathrm{~g}$ agar per $1 \mathrm{~L})$, and incubated at temperatures of $18,21,25$, and $28^{\circ} \mathrm{C}$. At 6-h intervals after inoculation, the agar media were stained with Gram's iodine to examine starch hydrolysis by the formation of clear halos around bacterial colonies due to enzyme activity. A definite clear zone formed around a bacterial colony was considered to be a positive response for starch hydrolytic activity $(+)$ and no formation of the clear zone negative (-).

Effect of bacterial treatment on inhibition of root rot caused by $C$. destructans on ginseng root discs and in pots. Two bacterial isolates were grown in BHI broth at $28^{\circ} \mathrm{C}$ for 2 days with shaking at $200 \mathrm{rpm}$. C. destructans KACC 41077 was grown on PDA at $21^{\circ} \mathrm{C}$ for 2 weeks. Four-year-old ginseng roots were surface-sterilized with $70 \% \mathrm{EtOH}$ for $5 \mathrm{~min}, 1 \% \mathrm{NaOCl}$ for $5 \mathrm{~min}$, and rinsed twice with SDW. These ginseng roots were cut to discs about $0.5-\mathrm{cm}$ thick and $2.5-\mathrm{cm}$ wide and placed in Petri dishes with sufficient moisture provided by inclusion of water-soaked cotton swabs. Twenty microliters of bacterial suspensions at $10^{6} \mathrm{cfu} / \mathrm{ml}$ and $10^{8} \mathrm{cfu} / \mathrm{ml}$ were spotted on the center of the root discs and dried for $5 \mathrm{~min}$ in air in a clean bench. Mycelial plugs of $C$. destructans culture were inoculated on the central region of root discs and incubated at $21{ }^{\circ} \mathrm{C}$. Roots were examined daily for development of root rot symptoms. Three days after inoculation, the degree of rotting was scored using the following disease severity rating system: 0 , no discoloration; 1 , yellowish discoloration; 2 , mild brown rot; 3 , brown rot; 4 , severe rot (Jeon et al., 2003).

For the pathogen inoculum for pot experiment, rice hull medium (rice hull 1: sand 4: distilled water 1.5) was sterilized by autoclaving at $121^{\circ} \mathrm{C}$ for $20 \mathrm{~min}$, inoculated with several plugs of PDA culture of $C$. destructans, and 
incubated at $21{ }^{\circ} \mathrm{C}$ for 14 days. The rice hull cultures of the fungus were homogenized and diluted 100-fold with SDW. Four-year-old ginseng roots were surface-disinfected with $70 \% \mathrm{EtOH}$ for $5 \mathrm{~min}, 2 \% \mathrm{NaOCl}$ for $5 \mathrm{~min}$, and rinsed twice with SDW. These ginseng roots were dipped in antifungal bacterial suspensions at two concentrations $\left(10^{6}\right.$ $\mathrm{cfu} / \mathrm{ml}$ and $10^{8} \mathrm{cfu} / \mathrm{ml}$ ) for $40 \mathrm{~min}$ and dried for $1 \mathrm{~h}$ at room temperature in a clean bench. Distilled water was used as the control. The roots were planted in rice hull medium containing different concentrations of fungal rice hull culture as inoculum $(0.2,1.0$, and $5.0 \%)$ and incubated at $21^{\circ} \mathrm{C}$. Rot symptom development on the ginseng roots was examined visually 20 days after inoculation, based on disease severity of $0-5$, with $0=$ no visible lesions, $1=$ brown lesions up to $0.9 \mathrm{~mm}$ in diameter, $2=$ dark brown lesions of $1.0-4.0 \mathrm{~mm}, 3=$ black lesions of $4.0-7.0 \mathrm{~mm}, 4=$ black lesions $>7.0 \mathrm{~mm}$, coalesced with each other, and $5=$ mostly coalesced black lesions with $>70 \%$ (or full) rotting (Rahman and Punja, 2005).

Population changes of bacterial isolates on ginseng root discs. Bacterial suspensions at concentrations of $10^{8} \mathrm{cfu} / \mathrm{ml}$ and $10^{6} \mathrm{cfu} / \mathrm{ml}$ were applied on 4-year-old ginseng root discs with or without $C$. destructans inoculation, as described above. Inoculated root discs were placed in Petri dishes with sufficient moisture supplied by inclusion of a water-soaked cotton swabs, and incubated at $21^{\circ} \mathrm{C}$ in an incubation chamber. Symptom development and bacterial population changes on ginseng root discs were examined daily for 7 days after inoculation. To examine bacterial populations, whole root discs were ground in $10 \mathrm{ml}$ sterile distilled water, diluted serially, plated on BHI agar, and incubated at $28^{\circ} \mathrm{C}$. After 2 days, colonies formed on the plates were counted and converted to log cfu per root disc. Each treatment was replicated three times.

Scanning electron microscopy for antagonistic effects of bacterial isolates on $C$. destructans. $C$. destructans cultures grown on PDA for 14 days were mixed with the bacterial suspensions $\left(10^{8} \mathrm{cfu} / \mathrm{ml}\right.$ and $\left.10^{6} \mathrm{cfu} / \mathrm{ml}\right)$ of the two Bacillus species grown on BHI for 2 days, with shaking at $200 \mathrm{rpm}$. After incubation for $24 \mathrm{~h}$, mycelia plugs of the fungus were fixed in Karnovsky's fixative in $0.05 \mathrm{M}$ cacodylate buffer at $\mathrm{pH} 7.2,4^{\circ} \mathrm{C}$ for $4 \mathrm{~h}$ (Karnovsky, 1965). Specimens were then washed three times with $0.05 \mathrm{M}$ cacodylate buffer for $15 \mathrm{~min}$ each time. The specimens were post-fixed in $1.0 \% \mathrm{OsO}_{4}$ in $0.05 \mathrm{M}$ cacodylate buffer (pH 7.2) at $4{ }^{\circ} \mathrm{C}$ for $4 \mathrm{~h}$ and then washed briefly with distilled water three times. Then the specimens were dehydrated in an ethanol series of 30, 50, 70, 80, and 90\% for $10 \mathrm{~min}$ at each concentration, and finally in $100 \%$ ethanol three times for $10 \mathrm{~min}$ each time. Specimens were then transited with $100 \%$ isoamylacetate twice for $10 \mathrm{~min}$ each at room temperature, critical-point dried, and coated with gold with a sputter coater (JFC-1110E, JEOL, Tokyo, Japan). The specimens were observed under a scanning electron microscope (JSM-5410LV, JEOL) at $20 \mathrm{kV}$.

Histological responses of ginseng root discs to bacterial treatment. Bacterial suspensions at $10^{8} \mathrm{cfu} / \mathrm{ml}$ and $10^{6} \mathrm{cfu} /$ $\mathrm{ml}$ were inoculated into the pith region at the center of 4year-old ginseng root discs and incubated at $21{ }^{\circ} \mathrm{C}$. After 8 days, root tissue segments from infection sites were cut with a razor blade and fixed in Karnovsky's fixative in cacodylate buffer (pH 7.0) for $4 \mathrm{~h}$ (Karnovsky, 1965). The segments were rinsed with the same buffer three times for $20 \mathrm{~min}$ each and post-fixed in $1 \% \mathrm{OsO}_{4}$ for $2 \mathrm{~h}$. The samples were washed briefly in distilled water, en bloc stained in $0.5 \%$ uranyl acetate at $4{ }^{\circ} \mathrm{C}$ overnight, and then dehydrated in an ethanol series of $30 \%$ through $100 \%$ for $10 \mathrm{~min}$ each. The samples were further dehydrated in propylene oxide and embedded in Spurr's epoxy resin (Spurr, 1969). For light microscopy, the embedded specimens were sectioned to $600-\mathrm{nm}$ thickness with a glass knife on an MT$\mathrm{X}$ ultramicrotome (RMC, Inc., Tucson, AZ), and observed under a compound light microscope (Axiophot, Zeiss, Germany) after staining with $0.1 \%$ toluidine blue $\mathrm{O}$.

\section{Results}

In vitro screening of antifungal activity of bacterial isolates against $\boldsymbol{C}$. destructans. In total, 174 bacterial isolates collected from mountain areas, mushrooms, and various crop fields were tested for antifungal activity against $C$. destructans. Among them, eight isolates were effective in significantly reducing mycelial growth of the pathogen, compared to the untreated control (Table 1). In particular,

Table 1. Effects of microbial treatments on mycelia growth of Cylindrocarpon destructans examined in the dual culture of the pathogen and microbes on PDA

\begin{tabular}{ccc}
\hline \hline Treatment & Mycelial growth $(\mathrm{mm})$ & ${\text { Inhibition rate }(\%)^{\mathrm{a}}}^{\mathrm{a}}$ \\
\hline A2 & $18.7 \pm 1.4^{\mathrm{b}}$ & 32.7 \\
I4 & $9.5 \pm 1.1$ & 65.8 \\
I5 & $16.9 \pm 1.0$ & 39.2 \\
MR2 & $24.8 \pm 1.4$ & 10.8 \\
T-D4 & $16.8 \pm 1.4$ & 39.6 \\
T-F1 & $19.4 \pm 1.2$ & 30.2 \\
yD16 & $8.4 \pm 1.2$ & 69.8 \\
Control $^{\mathrm{c}}$ & $27.8 \pm 0.9$ & - \\
\hline
\end{tabular}

${ }^{\mathrm{a}}$ Inhibition rate $(\%)=($ mycelial growth in control - mycelial growth in treatment $) /($ mycelial growth in control $) \times 100$

${ }^{b}$ Figures are averages and standard deviations of three replications.

${ }^{\mathrm{c}}$ Control: sterile distilled water 


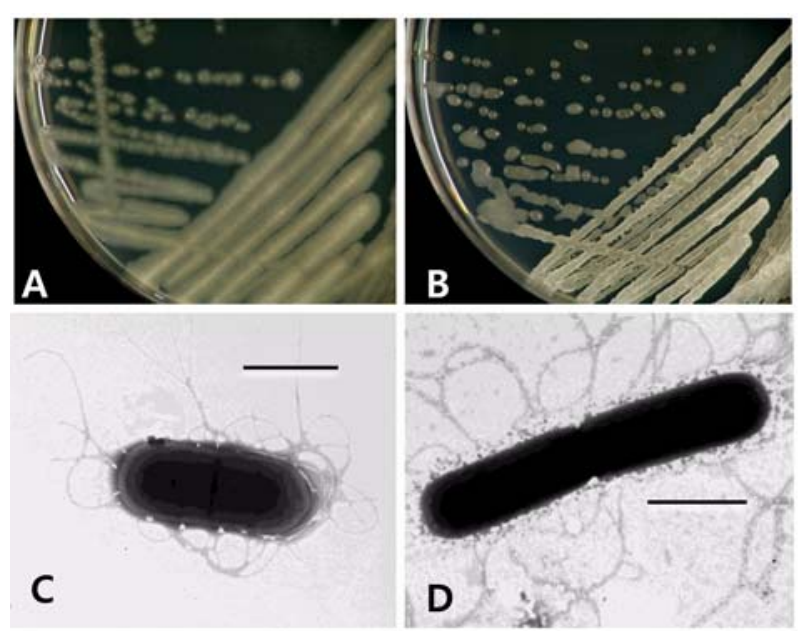

Fig. 1. Cultural and morphological characteristics of bacterial isolates Bacillus subtilis I4 (A, C) and B. amyloliquefaciens yD16 (B, D), showing cream-colored, flat or raised colonies sometimes with undulate margins (A, B) and rod-shaped bacterial cells of $\leq 1.0 \mu \mathrm{m}$ (diameter) $\times$ ca. $2.0 \mu \mathrm{m}$ (length) with more than four peritrichous flagella. Bars $=1.0 \mu \mathrm{m}$.

bacterial isolates I4 and yD16 obtained from forest soils showed relatively higher inhibitory activity of over $60 \%$ against mycelial growth of $C$. destructans compared to other isolates.

Identification of the antifungal bacteria. Two bacterial isolates, I4 and yD16, formed similar cream-colored, flat or raised colonies, sometimes with undulate margins, rodshaped, $\leq 1.0 \mu \mathrm{m}$ (diameter) $\times$ ca. $2.0 \mu \mathrm{m}$ (length), and had more than four peritrichous flagella (Fig. 1). They were all Gram-positive, endospore-forming bacteria that were positive for oxidase activity (data not shown). The carbon source assimilation of the bacterial isolates examined with the Biolog GN test kit (Biolog Inc., Hayward, Co., CA) showed a maximum similarity, with $99.8 \%$ identity, to Bacillus subtilis and B. amyloliquefaciens for isolate yD16, as it utilized 20 carbon sources including sorbitol, but not 29 carbon sources including mannitol (data not shown). Analysis of 16S rRNA gene sequences (that was given GenBank accession no. JN794569) for isolate I4 showed the highest homology (99\%), with $\mathrm{E}$ value of 0.0 , to $B$. subtilis strains, including GenBank accession numbers of HM224387.1, GQ452909.3, FJ644629.1, and HM10330.1; for isolate yD16 (GenBank accession no. JN794570), the highest homology (99\%) with $\mathrm{E}$ value of 0.0 was shown to $B$. amyloliquefaciens strains, including HQ179100.1, HQ113235.1, HM752244.1, and HM055608.1. Therefore, I4 and yD16 were identified as B. subtilis and B. amyloliquefaciens,

Table 2. Effect of nutrient concentration on antagonistic activity of Bacillus subtilis I4 and B. amyloliquefaciens yD16 to mycelial growth of Cylindrocarpon destructans on agar medium added with potato-dextrose broth

\begin{tabular}{cccccc}
\hline \hline & \multicolumn{5}{c}{ Mycelial growth (mm) of C. destructans } \\
\cline { 2 - 6 } Treatment & \multicolumn{5}{c}{ Nutrient concentration (\%) ${ }^{\mathrm{a}}$} \\
\cline { 2 - 6 } & 0 & 25 & 50 & 75 & 100 \\
\hline Control $^{\mathrm{b}}$ & $29.6 \pm 1.4^{\mathrm{c}}$ & $35.0 \pm 0.0$ & $35.0 \pm 0.0$ & $35.0 \pm 0.0$ & $40.0 \pm 0.0$ \\
I4 & $4.3 \pm 0.4(85.5)^{\mathrm{d}}$ & $9.6 \pm 0.9(72.6)$ & $11.1 \pm 0.9(68.3)$ & $11.6 \pm 1.0(66.9)$ & $12.3 \pm 1.2(69.2)$ \\
yD16 & $12.2 \pm 1.5(59.8)$ & $10.6 \pm 0.7(69.7)$ & $14.9 \pm 0.9(57.4)$ & $12.4 \pm 0.9(64.6)$ & $13.2 \pm 0.7(67.0)$ \\
\hline
\end{tabular}

${ }^{\text {a }}$ Concentrations (\%) relative to potato dextrose broth $(26.6 \mathrm{~g} / \mathrm{L})$ as $100 \%$

${ }^{\mathrm{b}}$ Conrol: sterile distilled water

${ }^{\mathrm{c}}$ Figures are averages and standard deviations of three replications.

${ }^{\mathrm{d}}$ Figures in parentheses are inhibition rates (\%) of mycelia growth compared to untreated controls.

Table 3. Effect of incubation temperature on mycelial growth of Cylindrocarpon destructans treated with antifungal bacteria Bacillus subtilis $\mathrm{I} 4$ and B. amyloliquefaciens yD16

\begin{tabular}{|c|c|c|c|c|c|}
\hline \multirow{3}{*}{ Treatment } & \multicolumn{5}{|c|}{ Mycelial growth (mm) of C. destructans } \\
\hline & \multicolumn{5}{|c|}{ Incubation temperature $\left({ }^{\circ} \mathrm{C}\right)$} \\
\hline & 15 & 18 & 21 & 25 & 28 \\
\hline Control & $27.6 \pm 0.8^{\mathrm{a}}$ & $29.6 \pm 0.8$ & $36.1 \pm 1.9$ & $25.4 \pm 0.8$ & $0.0 \pm 0.0$ \\
\hline $\mathrm{I} 4$ & $12.7 \pm 0.0(54.0)$ & $10.3 \pm 0.6(65.2)$ & $11.1 \pm 0.5(69.3)$ & $5.4 \pm 0.4(78.7)$ & $0.0 \pm 0.0(-)^{\mathrm{c}}$ \\
\hline yD16 & $11.0 \pm 1.2(60.1)$ & $9.0 \pm 0.3(69.6)$ & $9.0 \pm 0.7(75.1)$ & $6.3 \pm 0.6(75.2)$ & $0.0 \pm 0.0(-)$ \\
\hline
\end{tabular}

${ }^{a}$ Figures are averages and standard deviations of three replications.

${ }^{b}$ Figures in parentheses are inhibition rates (\%) of mycelia growth compared to untreated controls.

${ }^{\mathrm{c}}$ No pathogen mycelial growth at 28 . 
respectively, based on physiological and phylogenetic analyses.

Antifungal activities of the bacterial isolates at different nutrient and temperature conditions. The two bacterial isolates (B. subtilis I4 and B. amyloliquefaciens yD16) were tested for antifungal activity against $C$. destructans under different nutrient and temperature conditions during incubation. For nutrient concentrations, B. subtilis I4 was more effective in reducing the mycelial growth of the pathogen on medium with a lower nutrient concentration compared to higher concentrations (Table 2). However, there was no remarkable difference in the inhibitory activity of B. amyloliquefaciens yD16 among the nutrient concentrations tested.

For incubation temperatures, both bacterial isolates showed a gradual increase in antifungal activity against $C$. destructans with increasing temperature to $25^{\circ} \mathrm{C}$; antifungal activity of the bacterial isolates was not determined at $28^{\circ} \mathrm{C}$ because no pathogen mycelial growth occurred at this temperature (Table 3 ).

Starch hydrolytic activity of the bacterial isolates. Starch hydrolytic activity for both bacteria was seen as early as 12-42 $\mathrm{h}$ after inoculation, depending on temperature (earlier at higher temperature), in the high-density $\left(1 \times 10^{8}\right.$ $\mathrm{cfu} / \mathrm{ml}$ ) inoculum, whereas it occurred later in the lowdensity inoculum (Table 4). The appearance of starch hydrolytic activity was shortened proportionally with the increase in inoculum concentrations and temperature. No starch hydrolytic activity was produced at $1 \times 10^{4} \mathrm{cfu} / \mathrm{ml}$ in both $B$. subtilis $\mathrm{I} 4$ and $B$. amyloliquefaciens yD16 at $18{ }^{\circ} \mathrm{C}$, while it was produced $12 \mathrm{~h}$ after incubation at $1 \times 10^{8} \mathrm{cfu} /$ $\mathrm{ml}$ at $28^{\circ} \mathrm{C}$. There was little difference in the appearance

Table 4. Effect of incubation temperature and initial inoculum density of Bacillus subtilis I4 (I) and B. amyloliquefaciens yD16 (Y) on

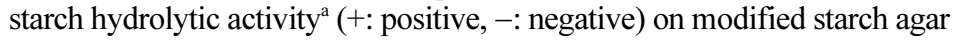

\begin{tabular}{|c|c|c|c|c|c|c|c|c|c|c|c|c|c|c|c|c|c|c|c|c|c|c|c|c|c|}
\hline \multirow{3}{*}{$\begin{array}{c}\text { Temperature } \\
\left({ }^{\circ} \mathrm{C}\right)\end{array}$} & \multirow{3}{*}{$\begin{array}{l}\text { Concentration } \\
(\mathrm{cfu} / \mathrm{ml})\end{array}$} & \multicolumn{24}{|c|}{ Hours of incubation } \\
\hline & & \multicolumn{2}{|c|}{6} & \multicolumn{2}{|c|}{12} & \multicolumn{2}{|c|}{18} & \multicolumn{2}{|c|}{24} & \multicolumn{2}{|c|}{30} & \multicolumn{2}{|c|}{36} & \multicolumn{2}{|c|}{42} & \multicolumn{2}{|c|}{48} & \multicolumn{2}{|c|}{54} & \multicolumn{2}{|c|}{60} & \multicolumn{2}{|c|}{66} & \multicolumn{2}{|c|}{72} \\
\hline & & I & $\mathrm{Y}$ & I & $\mathrm{Y}$ & I & $\mathrm{Y}$ & I & $\mathrm{Y}$ & I & $\mathrm{Y}$ & I & $\mathrm{Y}$ & I & $\mathrm{Y}$ & I & $\mathrm{Y}$ & I & $\mathrm{Y}$ & I & $\mathrm{Y}$ & $\mathrm{I}$ & $\mathrm{Y}$ & I & $\mathrm{Y}$ \\
\hline \multirow{3}{*}{18} & $10^{8}$ & $-^{\mathrm{a}}$ & - & - & - & - & - & - & - & - & - & - & - & + & + & + & + & + & + & + & + & + & + & + & + \\
\hline & $10^{6}$ & - & - & - & - & - & - & - & - & - & - & - & - & - & - & - & - & - & - & - & - & + & - & + & - \\
\hline & $10^{4}$ & - & - & - & - & - & - & - & - & - & - & - & - & - & - & - & - & - & - & - & - & - & - & - & - \\
\hline \multirow{3}{*}{21} & $10^{8}$ & - & - & - & - & - & - & - & - & + & + & + & + & + & + & + & + & + & + & + & + & + & + & + & + \\
\hline & $10^{6}$ & - & - & - & - & - & - & - & - & - & - & - & - & + & - & + & + & + & + & + & + & + & + & + & + \\
\hline & $10^{4}$ & - & - & - & - & - & - & - & - & - & - & - & - & - & - & - & - & - & - & + & + & + & + & + & + \\
\hline \multirow{3}{*}{25} & $10^{8}$ & - & - & - & - & - & - & - & + & - & + & + & + & + & + & + & + & + & + & + & + & + & + & + & + \\
\hline & $10^{6}$ & - & - & - & - & - & - & - & - & - & - & - & + & + & + & + & + & + & + & + & + & + & + & + & + \\
\hline & $10^{4}$ & - & - & - & - & - & - & - & - & - & - & - & - & + & + & + & + & + & + & + & + & + & + & + & + \\
\hline \multirow{3}{*}{28} & $10^{8}$ & - & - & + & + & - & - & + & + & + & + & + & + & + & + & + & + & + & + & + & + & + & + & + & + \\
\hline & $10^{6}$ & - & - & - & + & - & - & + & + & + & + & + & + & + & + & + & + & + & + & + & + & + & + & + & + \\
\hline & $10^{4}$ & - & - & - & - & - & - & - & + & + & + & + & + & + & + & + & + & + & + & + & + & + & + & + & + \\
\hline
\end{tabular}

a +: clear halos formed, -: not formed around bacterial cultures by enzyme activity

Table 5. Effect of bacterial treatment (Bacillus subtilis I4 and B. amyloliquefaciens yD16) on rot symptom development in ginseng root discs with or without inoculation of the pathogen Cylindrocarpon destructans 8 days after inoculation

\begin{tabular}{ccccccc}
\hline \hline \multirow{2}{*}{$\begin{array}{c}\text { Bacterial } \\
\text { treatment }\end{array}$} & \multirow{2}{*}{$\begin{array}{c}\text { Pathogen } \\
\text { inoculation }\end{array}$} & \multicolumn{5}{c}{ Rot symptom severity $^{\mathrm{a}}$} \\
\cline { 3 - 7 } & & 0 (Control) & $10^{2}$ & $10^{4}$ & $10^{6}$ & $10^{8}$ \\
\cline { 3 - 7 } & - & $0.0 \pm 0.0^{\mathrm{b}}$ & $0.0 \pm 0.0$ & $0.0 \pm 0.0$ & $0.0 \pm 0.0$ & $0.0 \pm 0.0$ \\
$\mathrm{n}$ & - & $0.0 \pm 0.0$ & $0.0 \pm 0.0$ & $0.0 \pm 0.0$ & $0.0 \pm 0.0$ \\
\hline yD16 & + & \multirow{2}{*}{$4.0 \pm 0.0$} & $3.0 \pm 0.0$ & $1.0 \pm 1.0$ & $0.7 \pm 1.2$ & $3.3 \pm 0.6$ \\
I4 & + & $0.3 \pm 0.6$ & $0.3 \pm 0.6$ & $0.0 \pm 0.0$ & $2.0 \pm 0.0$ \\
\hline
\end{tabular}

${ }^{a}$ Rot symptom severity: 0, no discoloration; 1, yellowish discoloration; 2, mild brown rot; 3, brown rot; 4, severe (early) rot (rotting 3 days after inoculation) (Jeon et al., 2003).

${ }^{\mathrm{b}}$ Figures are averages and standard deviations of three replications. 
time of enzyme activity between the bacterial isolates, regardless of temperature and initial inoculum density.

\section{Effect of bacterial treatment on inhibition of root rot} caused by $C$. destructans on ginseng root discs and in pots. No rot symptoms, except a slight yellowish discoloration, were produced until 8 days after inoculation on ginseng root discs treated with the antagonistic bacteria alone (Table 5). Initial rot symptoms appeared on root discs inoculated with $C$. destructans alone 3 days after inoculation, turned to brown rot 7 days after inoculation, and completely rotted 8-10 days after inoculation; however, rot symptom development was reduced by treatment with the antifungal bacteria (Table 5). The rot symptom reduction rate varied depending on the bacterial inoculum density, among which $1 \times 10^{6} \mathrm{cfu} / \mathrm{ml}$ for both bacterial isolates was most effective. The least symptom reduction after bacterial treatment was produced at the highest inoculum density $\left(1 \times 10^{8} \mathrm{cfu} / \mathrm{ml}\right)$ for both bacterial isolates.

In pot experiment, the ginseng roots inoculated with $C$. destructans alone were severely rotted, with a severity index of 4.67, while treatment with both bacterial isolates significantly reduced root rot disease development on 4year-old ginseng with varying degrees of control efficacy, depending on bacterial species and inoculum density (Table 6, Fig. 2). The highest control efficacies were achieved after bacterial treatment at the lower concentration $\left(10^{6} \mathrm{cfu} / \mathrm{ml}\right.$; $64.2-71.5 \%$ control efficacy) than at the higher concentration $\left(10^{8} \mathrm{cfu} / \mathrm{ml} ; 25.1-39.4 \%\right.$ control efficacy) for $B$. subtilis I4 and B. amyloliquefaciens yD16, respectively.

Population changes of bacterial isolates on ginseng root discs at different initial inoculum concentrations. When
Table 6. Effect of bacterial treatment (Bacillus subtilis I4 and $B$. amyloliquefaciens yD16) at different concentrations on control of ginseng root rot caused by Cylindrocarpon destructans

\begin{tabular}{|c|c|c|c|}
\hline \multicolumn{2}{|c|}{ Treatment } & \multirow[b]{2}{*}{ Rot severity } & \multirow{2}{*}{$\begin{array}{c}\text { Control } \\
\text { efficacy }(\%)\end{array}$} \\
\hline $\begin{array}{l}\text { Bacterial } \\
\text { isolate }\end{array}$ & $\begin{array}{l}\text { Concentration } \\
(\mathrm{cfu} / \mathrm{ml})\end{array}$ & & \\
\hline Control & & $4.67 \pm 0.52^{c} X^{d}$ & - \\
\hline \multirow[t]{2}{*}{ I4 } & $10^{6}$ & $1.33 \pm 0.52 \mathrm{Z}$ & 71.5 \\
\hline & $10^{8}$ & $2.83 \pm 0.98 \mathrm{YZ}$ & 39.4 \\
\hline \multirow[t]{2}{*}{ yD16 } & $10^{6}$ & $1.67 \pm 0.52 \mathrm{Z}$ & 64.2 \\
\hline & $10^{8}$ & $3.50 \pm 0.55 \mathrm{Y}$ & 25.1 \\
\hline
\end{tabular}

${ }^{\text {a }}$ Rot severity was examined 20 days after inoculation by scoring indices as $0=$ no visible lesions, $1=$ brown lesions up to $0.9 \mathrm{~mm}$ in diameter, $2=$ dark brown lesions of 1.0 to $4.0 \mathrm{~mm}, 3=$ black lesions of 4.0-7.0 mm, $4=$ black lesions $>7.0 \mathrm{~mm}$, coalesced with each other, $5=$ mostly coalesced black lesions, $>70 \%$ (or fully) rotten roots (Rahman and Punja, 2005).

${ }^{\mathrm{b}}$ Control efficacy $(\%)=($ rot severity of control - rot severity of treatment $) /($ rot severity of control) $\times 100$

${ }^{c}$ Figures are averages and standard deviations of six replications.

${ }^{\mathrm{d}}$ The same letters in a column denote no significant difference at $P=$ 0.05 by Duncan's multiple range test (DMRT).

bacteria alone were given to ginseng root discs at $10^{8} \mathrm{cfu} /$ $\mathrm{ml}$, the bacterial populations of both isolates maintained the initial inoculum density until 7 days after inoculation. However, bacterial populations from the low inoculum density of $10^{6} \mathrm{cfu} / \mathrm{ml}$ decreased sharply 2 to 3 days after inoculation (Fig. 3A). On the other hand, when the bacteria were given together with inoculation of $C$. destructans at $10^{8} \mathrm{cfu} / \mathrm{ml}$, the bacterial population increased initially and only became stationary 7 days after inoculation (Fig. 3B). Bacterial populations from $10^{6} \mathrm{cfu} / \mathrm{ml}$ on ginseng root discs inoculated with $C$. destructans also increased or maintained the initial bacterial density for 5 to 6 days after inoculation
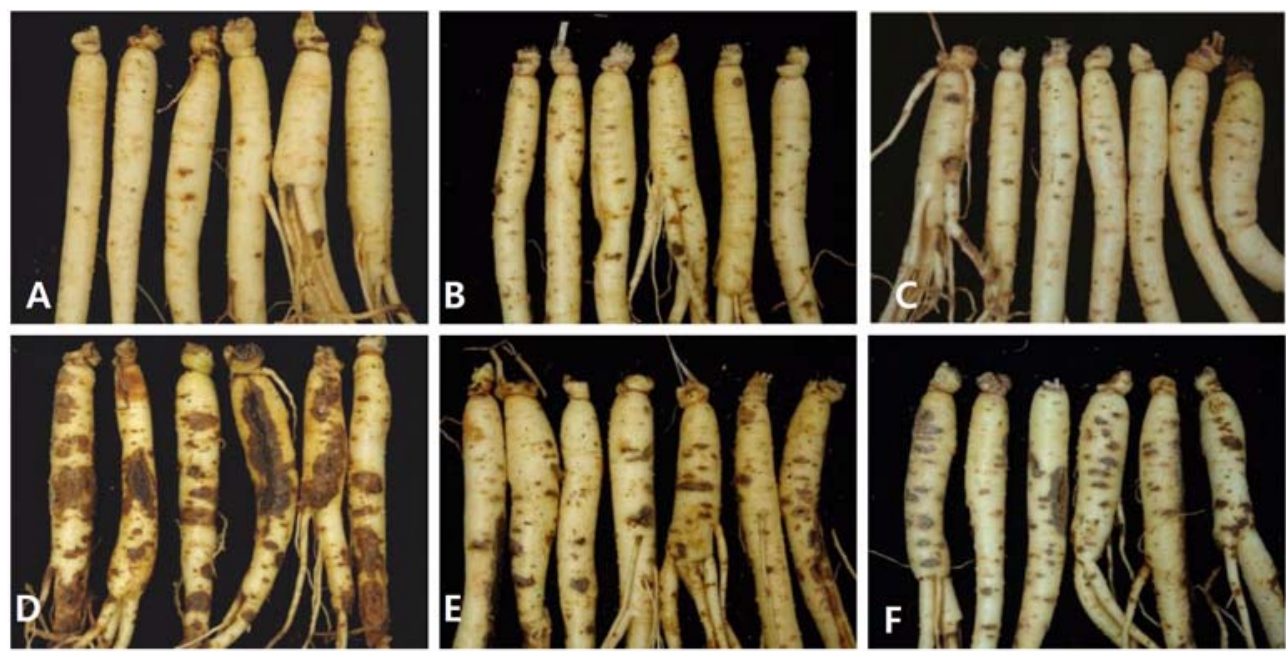

Fig. 2. Effect of bacterial treatments (Bacillus subtilis $\mathrm{I} 4<\mathrm{B}, \mathrm{E}>$ and $B$. amyloliquefaciens $\mathrm{yD} 16<\mathrm{C}, \mathrm{F}>$ ) on rot symptom development in 4-year-old ginseng roots caused by Cylindrocarpon destructans. A: no bacterial treatment and pathogen inoculation; D: pathogen inoculation only. 

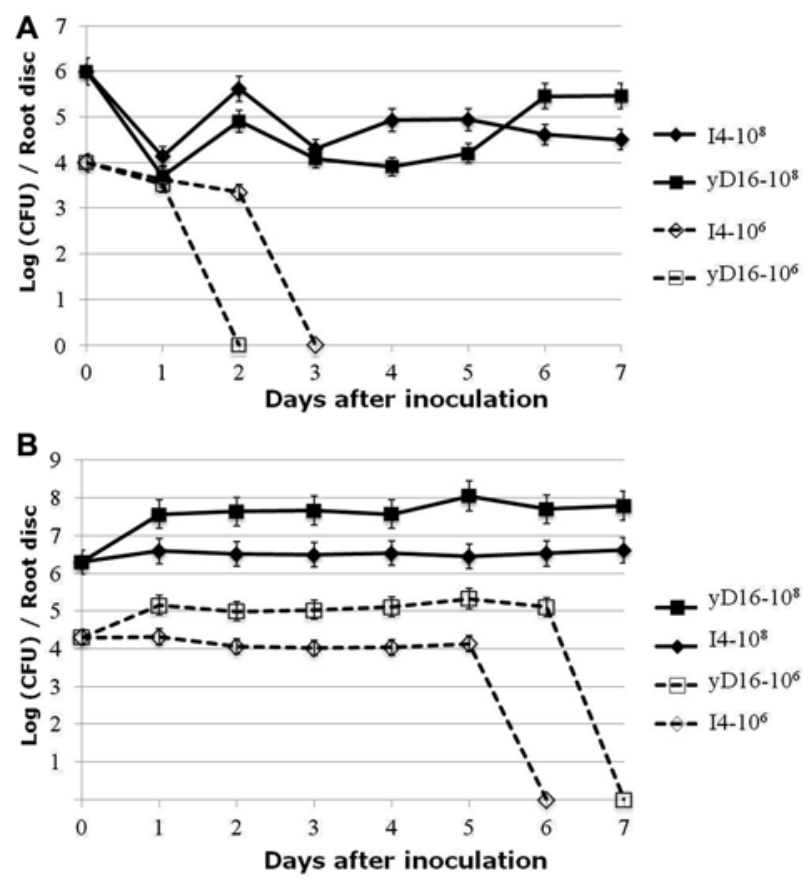

Fig. 3. Population changes of Bacillus subtilis $\mathrm{I} 4$ and B. amyloliquefaciens yD16 from low $\left(10^{6} \mathrm{cfu} / \mathrm{ml}\right)$ and high $\left(10^{8} \mathrm{cfu} / \mathrm{ml}\right)$ initial inoculum on 4-year-old ginseng root discs with (B) and without (A) inoculation of Cylindrocarpon destructans. Marks and vertical bars are averages and standard deviations of three replications, respectively.

and thereafter decreased.

Scanning electron microscopy for antagonistic effects of Bacillus species on $\boldsymbol{C}$. destructans. Scanning electron microscopy of $C$. destructans showed intact fungal hyphae with a smooth hyphal surface before bacterial treatment (Fig. A), while B. subtilis I4- and B. amyloliquefaciens yD16-treated fungal hyphae at $10^{6} \mathrm{cfu} / \mathrm{ml}$ appeared wrinkled and distorted, with a rough and dissolving hyphal

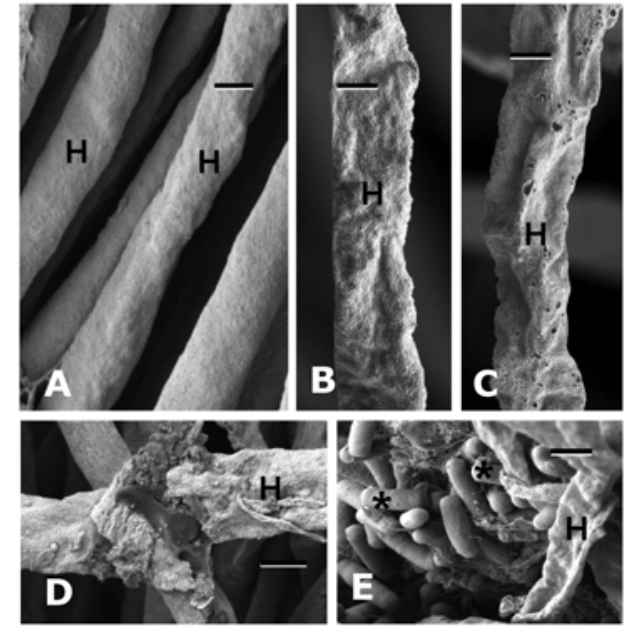

Fig. 4. Scanning electron micrographs of Cylindrocarpon destructans treated with Bacillus subtilis $\mathrm{I} 4(\mathrm{~B}, \mathrm{D})$ and $B$. amyloliquefaciens yD16 (C, E) at inoculum densities of $10^{6} \mathrm{cfu} /$ $\mathrm{ml}(\mathrm{B}, \mathrm{C})$ and $10^{8} \mathrm{cfu} / \mathrm{ml}(\mathrm{D}, \mathrm{E})$, showing wrinkled and distorted pathogen hyphae $(\mathrm{H})$ with rough and dissolute hyphal surfaces, compared to intact hyphal morphology with smooth surface in the no-treatment control. Asterisks in (E) denote bacterial cells on the pathogen hyphae $(\mathrm{H})$. Bars $=1.0 \mu \mathrm{m}$.

surface (Fig. 4B, C). When the pathogen was treated with a high-inoculum density of bacterial isolates, fungal hyphae were also similarly distorted and broken, as in low-inoculum density, accompanied by accumulation of bacterial cells on the fungal hyphae (Fig. 4D, E).

Histological responses of ginseng root tissues to Bacillus species. Light microscopy of ginseng root tissues treated with the two bacterial isolates at low concentrations $\left(10^{6}\right.$ $\mathrm{cfu} / \mathrm{ml}$ ) showed the formation of a wound periderm 8 days after treatment, as indicated by cell walls crossing parenchymatous cells (indication of cell divisions) under the inoculation sites (Fig. 5). However, no or little wound
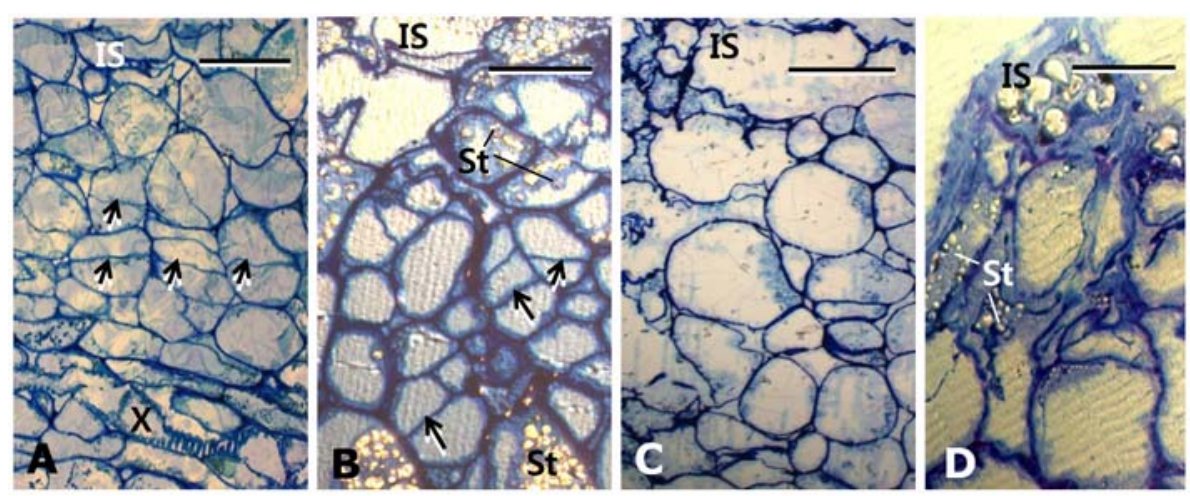

Fig. 5. Structural changes in 4-year-old ginseng root tissues interior to inoculation sites (IS) 8 days after treatment with Bacillus subtilis I4 (A, C) and B. amyloliquefaciens yD16 (B, D) at inoculum densities of $10^{6} \mathrm{cfu} / \mathrm{ml}(\mathrm{A}, \mathrm{B})$ and $10^{8} \mathrm{cfu} / \mathrm{ml}(\mathrm{C}$, D), showing cell wall divisions (arrows), an indication of wound periderm (boundary layer) formation (A, B), but no or little indication of wound periderm formation $(\mathrm{C}, \mathrm{D}) . \mathrm{St}=$ starch granules. Bars $=50 \mu \mathrm{m}$. 
periderm formation was noted in treatment with the highinoculum concentration $\left(10^{8} \mathrm{cfu} / \mathrm{ml}\right)$ of the bacterial isolates, which only showed damaged and darkened parenchymatous cells beneath the inoculation sites.

\section{Discussion}

In our study, two bacterial isolates identified as B. subtilis I4 and $B$. amyloliquefaciens yD16 had strong antagonistic activity against the causal pathogen of ginseng root rot, $C$. destructans. Their antagonistic activity to $C$. destructans varied depending on nutrient concentration and temperature during incubation in nutrient media. Antagonistic activity of $B$. subtilis I4 increased with increased nutrient concentration in the incubation medium, whereas no difference in antagonistic activity was noted for $B$. amyloliquefaciens yD16 in relation to nutrient conditions. Antagonistic activity of both bacterial isolates to $C$. destructans increased with increasing temperature, showing maximum activity at 21 ${ }^{\circ} \mathrm{C}$ and $25^{\circ} \mathrm{C}$.

All microbes in soil, both plant pathogens and biocontrol agents are affected by physicochemical characteristics of the soil, including temperature, moisture, and nutrient properties, which influence their activity, growth, and development (Coyne, 1999). For $C$. destructans, the temperature range for its survival is $5-25^{\circ} \mathrm{C}$, with no mycelia growth at and above $30^{\circ} \mathrm{C}$ (Cho et al., 1995). No mycelia growth was seen at $28^{\circ} \mathrm{C}$ in our study. Virulence of $C$. destructans is reduced in ginseng root tissue rot as temperature increases (Kim et al., 2009). The results suggest that the present bacterial isolates may display full capacity to weaken the root rot pathogen at $21^{\circ} \mathrm{C}-25^{\circ} \mathrm{C}$, at which temperature the defense responses of ginseng root tissues to pathogen attack are elevated (Kim et al., 2009).

Mass introduction of biocontrol agents into soil is required for their practical use in biological control of diseases under field conditions (Upadhyay and Rai, 1988), which may be achieved by increasing either the concentration or the mass of the biocontrol agents, or both. In our study, however, treatments with $B$. subtilis I4 and $B$. amyloliquefaciens yD16 showed good control of ginseng root rot caused by $C$. destructans at the lower inoculum concentration $\left(10^{6} \mathrm{cfu} / \mathrm{ml}\right)$ than at the higher one $\left(10^{8} \mathrm{cfu} /\right.$ $\mathrm{ml})$. Reasons for this can be derived from results of our in vitro experiments. First, starch hydrolytic activity of the bacterial isolates increased with the increase in inoculum concentration, which was related to ginseng root rot in a previous study (Jeon et al., 2010). Degraded starch granules were observed in ginseng root cells at a high inoculum concentration $\left(10^{8} \mathrm{cfu} / \mathrm{ml}\right)$, showing tissue rotting, while intact starch granules were present in cells of healthy root tissues inoculated with a low concentration $\left(10^{6} \mathrm{cfu} / \mathrm{ml}\right)$ (Jeon and Kim, 2008). Second, in our study, treatment with a highly concentrated bacterial inoculum inhibited wound periderm formation, which is a structural defense mechanism against plant pathogen infection (Agrios, 2005). This suggests that the more concentrated inoculum may reduce the capacity of the plant to resist pathogen infection. This phenomenon (wound periderm formation) is also found in ginseng root tissues treated with different inoculum concentrations of Paenibacillus polymyxa (Jeon et al., 2008) and is related to resistance and defense against fungal diseases caused by Colletotrichum spp. (in chili pepper) (Kim et al., 2004, 2008) and Bipolaris cactivora (in cactus) (Choi et al., 2010). Although a mass introduction of the bacterial isolates at high inoculum concentrations may not be hazardous for root rot disease, it is unlikely that bacterial populations will reach high population levels in natural conditions (Mavingui and Heulin, 1994; Jung et al., 2002).

In vitro antagonistic activity of $B$. subtilis $\mathrm{I} 4$ and $B$. amyloliquefaciens yD16 against $C$. destructans could be higher at higher initial inoculum concentrations as was found for a similar bacterial isolate, Paenibacillus polymyxa GBR-1, in previous studies (Jeon and Kim, 2008; Jeon et al., 2010). However, it is more important to have a high population density in situ at the time of pathogen infection on the rhizoplane rather than an initial inoculum density that may be controlled by mass introduction of biocontrol agents into the soil (Upadhyay and Rai, 1988). In our study, the bacterial populations from the low-concentration inoculum failed to colonize ginseng root tissues (disappeared rapidly on ginseng root discs) in the absence of the root-rot pathogen, but succeeded in colonizing root tissues inoculated with the pathogen. Scanning electron microscopy also showed that the pathogen (C. destructans) was damaged by the low-inoculum bacterial treatment as much as by the high inoculum treatment, supporting the higher efficacy in controlling ginseng root rot of the lower bacterial treatment than the higher concentration. Therefore, all the results suggest that the bacterial antagonists (B. subtilis I4 and $B$. amyloliquefaciens yD16) may have good potential to be developed as biocontrol agents against ginseng root rot caused by $C$. destructans.

\section{Acknowledgement}

This study was carried out with the financial support from the Office of Rural Development Administration, Republic of Korea.

\section{References}

Agrios, G. N. 2005. Plant Pathology, Fifth Edition. Elsevier Aca- 
demic Press, San Diego, CA. 922 pp.

Bae, Y.-S., Park, K. and Kim, C.-H. 2004. Bacillus spp. as biocontrol agents of root rot and phytophthora blight on ginseng. Plant Pathol. J. 20:63-66.

Brosius, J., Palmet, M. L., Kennedy, P. J. and Noller, H. F. 1978. Complete nucleotide sequence of a 16S ribosomal RNA gene from Escherichia coli. Proc. Natl. Acad. Sci. USA 75:48014805.

Cho, D. H., Ahn, I. P., Yu, Y. H., Ohh, S. H. and Lee, H. S. 1995. Effect of incubation period, temperature and $\mathrm{pH}$ on mycelia growth of Cylindrocarpon destructans (Zinssm.) Scholten causing root-rot of ginseng. Korean J. Ginseng Sci. 2:181187.

Choi, M.-O., Kim, S. G. and Kim, Y. H. 2010. Suppression of Bipolaris stem rot on cactus by heat-inactivated conidial suspension of Bipolaris cactivora. Plant Pathol. J. 26:231-237.

Chung, H. S. 1975. Studies on Cylindrocarpon destructans (Zins.) Scholten causing root rot of ginseng. Rep. Tottori Mycol. Inst. 12:127-138.

Coyne, M. S. 1999. Soil Microbiology: An Exploratory Approach. Delmar Publishers, New York, USA. 462 pp.

Haas, D. and G. Defago. 2005. Biological control of soil-borne pathogens by fluorescent pseudomonads. Nat. Rev. Microbiol. 3:307-319.

Handelsman, J. and Stabb, E. V. 1996. Biocontrol of soilborne plant pathogens. Plant Cell 8:1855-1869.

Jeon, Y. H., Chang, S. P., Hwang, I. and Kim, Y. H. 2003. Involvement of growth-promoting rhizobacterium Paenibacillus polymyxa in root rot of stored Korean ginseng. J. Microbiol. Biotechnol. 13:881-891.

Jeon, Y. H. and Kim, Y. H. 2008. Differential structural responses of ginseng root tissues to different initial inoculums levels of Paenibacillus polymyxa GBR-1. Plant Pathol. J. 24:352-356.

Jeon, Y. H., Kim, S. G., Hwang, I. G. and Kim, Y. H. 2010. Effects of initial inoculation density of Paenibacillus polymyxa on colony formation and starch-hydrolytic activity in relation to root rot in ginseng. J. Appl. Microbiol. 2:461-470.

Jeon, Y. H., Park, H., Lee, B.-D., Yu, Y. H., Chang, S. P., Kim, S. G., Hwang, I. and Kim, Y. H. 2008. First description of crwon gall on ginseng. Plant Pathol. J. 24:207-210.

Jung, W.-J., Jung, S.-J., An, K.-N., Jin, Y.-L., Park, R.-D., Kim, K.-Y., Shon, B.-K. and Kim, T.-H. 2002. Effect of chitinaseproducing Paenibacillus illinoisensis KJA-424 on egg hatching of root-knot nematode (Meloidogyne incognita). J. Microbiol. Biotechnol. 12:865-871.

Karnovsky, M. J. 1965. A formaldehyde-glutaraldehyde fixative of high osmolarity for use in electron microscopy. J. Cell Biol. 27:137A.

Kim, J. H., Jeon, Y. H., Park, H., Lee, B.-D., Cho, D. H., Park, B. Y., Khan, Z. and Kim, Y. H. 2006. The root-lesion nematode, Pratylenchus subpenetrans, on ginseng (Panax ginseng) in
Korea. Nematology 8:637-639.

Kim, J. H., Kim, S. G. and Kim, Y. H. 2009. Different structural modifications associated with development of ginseng root rot caused by Cylindrocarpon destructans. Plant Pathol. J. 25:15.

Kim, K.-H., Yoon, J.-B., Park, H.-G., Park, E. W. and Kim, Y. H. 2004. Structural modifications and programmed cell death of chili pepper fruit related to resistance responses to Colletotrichum gloeosporioides infection. Phytopathology 94:12951304.

Kim, S. G., Jang, Y., Kim, H. Y., Koh, Y. H. and Kim, Y. H. 2010. Comparison of microbial fungicides in antagonistic activities related to the biological control of phytophthora blight in chili pepper caused by Phytophthora capsici. Plant Pathol. J. 26:340-345.

Kim, S. G., Kim, Y.-H., Kim, H.-T. and Kim, Y. H. 2008. Effect of delayed inoculation after wounding on the development of anthracnose disease caused by Colletotrichum acutatum on chili pepper fruit. Plant Pathol. J. 24:392-399.

Lee, S. K. 2004. Fusarium species associated with ginseng (Panax ginseng) and their role in the root-rot of ginseng plants. Res. Plant Dis. 10:248-259.

Mavingui, P. and Heulin, T. 1994. In vitro chitinase and antifungal activity of a soil, rhizosphere and rhizoplane population of Bacillus polymyxa. Soil. Biol. Biochem. 26:801-803.

Ohh, S. H., Lee, S. K., Lee, J. H. and Han, S. C. 1983. New root rot disease of Panax ginseng due to Ditylenchus destructor Thorne. Korean J. Plant Prot. 25:169-173.

Park, K. J. 2001. Fitness analysis of the forecasting model for root rot progress of ginseng based on bioassay and soil environmental factors. Res. Plant Dis. 7:20-24.

Rahman, M. and Punja, Z. K. 2005. Biochemistry of ginseng root tissues affected by rust root symptoms. Plant Physiol. Biochem. 43:1103-1114.

Sang, M. K., Chiang, M. H., Yi, E. S., Park, K. W. and Kim, K. D. 2006. Biocontrol of Korean ginseng root rot caused by Phytophthora cactorum using antagonistic bacterial strains ISE13 and KJ1R5. Plant Pathol. J. 22:103-106.

Spurr, A. R. 1969. A low viscosity epoxy resin embedding medium for electron microscopy. J. Ultrastr. Res. 26:31-43.

Upadhyay, R. S. and Rai, B. 1988. Biocontrol agents of plant pathogens: Their use and practical constraints. In: Biocontrol of Plant Diseases Vol. 1, ed by K. G. Mukerji and K. L. Garg, pp. 15-36. CRC Press, Inc. Boca Raton, Florida, USA.

Weisburg, W., Barns, S. M., Pelletier, D. A. and Lane, D. J. 1991. $16 \mathrm{~S}$ ribosomal DNA amplification for phylogenetic study. $J$. Bacteriol. 173:697-703.

Yu, Y. H. 1987. Root rot diseases of Panax ginseng and their control in Korea. Korean J. Plant Pathol. 3:318-319.

Yu, Y. H. and Ohh, S. H. 1993. Research on ginseng diseases in Korea. Korean J. Ginseng Sci. 17:61-68. 